\title{
Behavior of sheep fed different sequences of ingredients in a spineless cactus (Nopalea cochenillifera Salm-Dyck) based-diet
}

\section{Comportamento de ovinos alimentados com diferentes seqüencias de ingredientes em dieta a base de palma forrageira ("Nopalea cochenillifera Salm-Dyck")}

\author{
FOTIUS, Anna Christine Alencar ${ }^{1}$; FERREIRA, Marcelo de Andrade ${ }^{1}$; BISPO, Safira \\ Valença $^{2}$; VÉRAS, Antônia Sherlânea Chaves ${ }^{1}$; SALLA, Luciane Elisete ${ }^{1}$; CHAGAS, \\ Juana Catarina ${ }^{1}$
}

\footnotetext{
${ }^{1}$ Universidade Federal Rural de Pernambuco, Departamento de Ciência Animal, Recife, Pernambuco, Brasil.

${ }^{2}$ Universidade Federal da Paraíba, Departamento de Ciência Animal, Areia, Paraíba, Brasil.

*Endereço para correspondência: lusalla@yahoo.br
}

\section{SUMMARY}

The purpose of this experiment was to evaluate the ingestive behavior of sheep fed diets containing different sequences of ingredients of a spineless cactus based diet because of the paucity of available information regarding the best method of feeding, especially in relation to the use of spineless cactus. The observed variables were daily time of eating, ruminating and idling. Five sheep were distributed into a $5 \times 5$ Latin Square with five treatments, five animals and five periods, the treatments $1-$ (TMR, total mixed ration) at 7:00 and 15:00h; $2-(\mathrm{C}$, concentrate $)$ at 7:00h, (SC, spineless cactus) at 8:00 h, (C) at 15:00h and (TGH, tifton grass hay) at 16:00h; $3-(\mathrm{C})$ at 7:00h, $(\mathrm{TGH})$ at 8:00h, $(\mathrm{C})$ at $15: 00 \mathrm{~h}$ and $(\mathrm{SC})$ at $16: 00 \mathrm{~h}$; $4-(\mathrm{SC})$ at $7: 00 \mathrm{~h},(\mathrm{C})$ at $8: 00 \mathrm{~h},(\mathrm{TGH})$ at 15:00 and $(\mathrm{C})$ at 16:00h and $5-(\mathrm{TGH})$ at 7:00h, (C) at $8: 00 \mathrm{~h},(\mathrm{SC})$ at $15: 00 \mathrm{~h}$ and (C) at 16:00h. No treatment effect on feeding activities (hour/day) in time total daily, but when activities were divided into periods, the sheep in sequence 3: concentrate/ hay/ concentrate/spineless cactus spent a longer time eating within the period from 7:00 to 11:00h than the sheep in sequences 1: total mixed ration (TMR) and 2: concentrate/ spineless cactus/ concentrate /hay. The digestibility of dry matter and matter organic was greater for concentrate/ spineless cactus/ concentrate/ hay and spineless cactus/ concentrate/ hay/ concentrate being recommended the use of the same as feeding strategy.

Keywords: feeding, non-fiber carbohydrates, rumination, total mixed ration

\section{RESUMO}

Objetivou-se com este estudo avaliar o comportamento ingestivo de ovinos alimentados com dietas contendo diferentes sequências de ingredientes a base de palma forrageira, devido à escassez de informações disponíveis sobre o melhor método de alimentação, especialmente ao uso da palma forrageira. As variáveis observadas foram tempo diário de ingestão, ruminação e ócio. Cinco ovinos foram distribuídos em um quadrado latino $5 \times 5$, com cinco tratamentos, cinco animais e cinco períodos, sendo os tratamentos: 1 - (ração totalmente misturada- TMR) às 7:00 e às 15:00h; 2 - (concentrado- C) às 7:00h, (palma forrageira$\mathrm{PF}$ ) às 8:00h, $(\mathrm{C})$ às 15:00h e (feno de capim tifton- FCT) às 16:00h; $3-(\mathrm{C})$ às 7:00h, $(\mathrm{FCT})$ às $8: 00 \mathrm{~h},(\mathrm{C})$ às 15:00h e $(\mathrm{PF})$ às 16:00h; $4-(\mathrm{PF})$ às 7:00h, (C) às 8:00h, (FCT) às 15:00 e (C) às $16: 00 \mathrm{~h}$ e $5-(\mathrm{FCT})$ às 7:00h, $(\mathrm{C})$ às $8: 00 \mathrm{~h},(\mathrm{PF})$ às $15: 00 \mathrm{~h}$ e $(\mathrm{C})$ às 16:00h. Não houve efeito de tratamento sobre as atividades de alimentação (horas/dia) no total de tempo diário. Porém quando as atividades foram divididas em períodos, os ovinos na sequência 3: concentrado/ feno/ concentrado/ palma passaram um tempo de ingestão maior no período de 7:00-11:00 h comparados aos da sequência 1: ração total misturada e 2: concentrado/ palma/ concentrado/ feno. A digestibilidade da matéria seca e da matéria orgânica foi maior para concentrado/ palma/ concentrado/ feno e palma/concentrado/feno/concentrado sendo recomendado o uso dos mesmos como estratégia alimentar.

Palavras-chave: alimentação, carboidratos não fibrosos, ruminação, ração totalmente misturada 


\section{INTRODUCTION}

The typical sheep management practice in northeast Brazil is to offer forage cactus in the morning after a feeding of concentrate. On most farms, there is a lack of skilled labor and equipment to provide this as a TMR. However, when this forage is supplied separate of fibrous sources, abrupt changes in the rumen environment may occur, leading to the onset of digestive disorders as a result of excessive non-fibrous carbohydrate (NFC) ingestion (NOCEK, 1997). More uniform rumen fermentation and better utilization of nutrients is observed when ingredients are consumed through TMR rather than separated feedings.

According to Shekarchian (2012) the TMR may be recommended mainly when concentrate is associated to high quality roughages. Therefore, fiber source must be initially supplied when feed is offered separately to provide appropriate fermentation and thus a stable rumen environment (NRC, 2007). Thus, the feeding behavior is important in assessing diets because it enables post adjustment for feed management to obtain better productive and reproductive performance (FRANÇA et al., 2009).

The objective of this study was to evaluate the effect of feeding systems (concentrated separately vs TMR) on feeding behavior due to selection and reduced food waste, especially in relation to the use of spineless cactus.

\section{MATERIAL AND METHODS}

The research was conducted in the Department of Animal Science of the Federal Rural University of
Pernambuco-UFRPE, located in the city of Recife in the state of Pernambuco, northeast Brazil. The study made use of five sheep of nondescript breeding, averaging $38.5 \mathrm{~kg}$, gifted with rumen cannule. The diet consisted of $31 \%$ hay (Tifton grass 85, C'ynodon spp.), 40.0\% spineless cactus (Nopalea cochenillifera Salm-Dyck), 29.0\% concentrate (55.7\% soybean meal, Glycine Max; 37.2\% corn, Zea mays) and $4.88 \%$ mineral mix. The treatments consisted of five feeding sequences as follows: 1 (TMR, total mixed ration) at 7:00 and $15: 00 \mathrm{~h} ; 2-(\mathrm{C}$, concentrate $)$ at $7: 00 \mathrm{~h}$, (SC, Spineless cactus) at 8:00h, (C) at 15:00h and (TGH, Tifton grass hay) at $16: 00 \mathrm{~h} ; 3-(\mathrm{C})$ at $7: 00 \mathrm{~h},(\mathrm{TGH})$ at $8: 00 \mathrm{~h},(\mathrm{C})$ at $15: 00 \mathrm{~h}$ and $(\mathrm{SC})$ at $16: 00 \mathrm{~h} ; 4-(\mathrm{SC})$ at $7: 00 \mathrm{~h},(\mathrm{C})$ at $8: 00 \mathrm{~h}$, $(\mathrm{TGH})$ at $15: 00$ and $(\mathrm{C})$ at 16:00h and $5-(\mathrm{TGH})$ at 7:00h, (C) at 8:00h, (SC) at 15:00h and $(\mathrm{C})$ at 16:00h (Table 1).

The diets were offered allowing $10 \%$ of leftover of the previous day consumption. The amount of each dietary component fed and the amount refused were recorded each day. Ingestive behavior parameters were recorded at $10 \mathrm{~min}$ intervals for 24 hours per day to each animal, according to the procedures of Martin \& Bateson (2007), and were classified into three main activities: eating time (ET), ruminating time (RT) and idling time (IT). Ruminal content samples ( \pm $400 \mathrm{~mL}$ ) were collected for six days at every zero hour; (immediately prior to feeding) and at 2;4;6;8 and $10 \mathrm{~h}$ after the first feeding. The apparent nutrient digestibility were determined following methodology described by Coelho da Silva \& Leão (1979), the contents of dry matter (DM) and neutral fiber detergent (NDF) by Silva \& Queiroz (2002). 
The experimental design was $5 \times 5$ Latin Square with five treatments, five animals and five periods. The SNK test was used for comparisons between means, with the level of significance set at $5 \%$, using the SAEG program (UFV, 2007).

Table 1. Chemical composition of ingredients and experimental diet

\begin{tabular}{lccccc}
\hline Item & Diet & $\begin{array}{c}\text { Spineless } \\
\text { cactus }\end{array}$ & $\begin{array}{c}\text { Tifton } \\
\text { hay }\end{array}$ & $\begin{array}{c}\text { Soybean } \\
\text { meal }\end{array}$ & $\begin{array}{c}\text { Ground } \\
\text { corn }\end{array}$ \\
\hline Dry matter $(\mathrm{g} / \mathrm{Kg} \mathrm{NM})$ & 334.3 & 171.0 & 917.6 & 901.1 & 891.4 \\
Organic matter $(\mathrm{g} / \mathrm{Kg} \mathrm{NM})$ & 910.8 & 894.7 & 936.8 & 933.9 & 984.0 \\
Crude protein $(\mathrm{g} / \mathrm{Kg} \mathrm{NM})$ & 128.1 & 29.1 & 51.9 & 530.5 & 89.2 \\
Ether extract $(\mathrm{g} / \mathrm{Kg} \mathrm{NM})$ & 21.0 & 13.3 & 22.7 & 40.2 & 25.0 \\
Neutral detergent fiber $(\mathrm{g} / \mathrm{Kg} \mathrm{NM})$ & 377.6 & 201.4 & 782 & 285.2 & 119.9 \\
Acid detergent fiber $(\mathrm{g} / \mathrm{Kg} \mathrm{NM})$ & 145.5 & 95.2 & 318.4 & 54.7 & 22.6 \\
Total carbohydrates $(\mathrm{g} / \mathrm{Kg} \mathrm{NM})$ & 761.7 & 852.3 & 862.1 & 378.6 & 852.3 \\
Non-fiber carbohydrates $(\mathrm{g} / \mathrm{Kg} \mathrm{NM})$ & 384.1 & 650.9 & 80.1 & 90.1 & 734.4 \\
\hline
\end{tabular}

$\mathrm{NM}=$ natural matter.

\section{RESULTS AND DISCUSSION}

The overall time (eating) behavioral variables of sheep fed different diet sequences are shown (Table 2). No treatment effect $(\mathrm{P}>0.05)$ was observed on the ingestive traits. In this study, the same values of neutral detergent fiber intake and dry matter $(\mathrm{P}>0.05)$, led to a lack of selection, only the sequence was changed, which indicates an adjustment over the course of the day with respect to the intake of diet ingredients. It is common to find differences between the parameters ingestive mainly in rumination time when diets vary in their fiber content (BEAUCHEMIN et al., 2003; CARVALHO et al., 2006; COSTA et al., 2012), but this was not observed this study.

Table 2. Dry matter and neutral detergent fiber intakes, apparent digestibility of dry and organic matter, and total rumination time, idle and ingestion of sheep fed in different sequences of food

\begin{tabular}{|c|c|c|c|c|c|c|c|}
\hline \multirow{2}{*}{\multicolumn{8}{|c|}{ Treatments }} \\
\hline Item & 1 & 2 & 3 & 4 & 5 & $\mathrm{P}$ & \\
\hline & Intake & & & & & & \\
\hline Dry matter $(\mathrm{kg} /$ day $)$ & 1.26 & 1.29 & 1.18 & 1.28 & 1.19 & $>0.50$ & 0.55 \\
\hline Neutral detergent fiber (kg/day) & 0.44 & 0.45 & 0.40 & 0.46 & 0.42 & $>0.50$ & 0.64 \\
\hline \multicolumn{8}{|c|}{ Apparent digestibility } \\
\hline Dry Matter ( g/Kg) & $0.70^{\mathrm{b}}$ & $0.75^{\mathrm{a}}$ & $0.69^{b}$ & $0.75^{\mathrm{a}}$ & $0.71^{b}$ & 0.002 & 0.15 \\
\hline Organic Matter $(g / K g)$ & $0.73^{\mathrm{b}}$ & $0.77^{\mathrm{a}}$ & $0.72^{\mathrm{b}}$ & $0.77^{\mathrm{a}}$ & $0.74^{\mathrm{b}}$ & 0.000 & 0.13 \\
\hline \multicolumn{8}{|c|}{ Feeding behavior } \\
\hline Rumination (hours/day) & 6.50 & 6.86 & 7.18 & 6.04 & 6.99 & $>0.05$ & 0.45 \\
\hline Idle (hours/day) & 14.4 & 13.97 & 13.50 & 14.59 & 13.63 & $>0.05$ & 0.26 \\
\hline Ingestion (hours/day) & 3.38 & 3.17 & 3.32 & 3.37 & 3.39 & $>0.05$ & 0.59 \\
\hline
\end{tabular}

Means followed by different superscripts in the same row are significantly different $(\mathrm{P}<0.05)$, SNK test. $1=$ Standart error of mean 
Although the rumination time not show significant difference $(\mathrm{P}>0.05)$ between the different dietary sequences, a brief comment is relevant, since outstanding behavior following: concentrate, hay, concentrate, spineless cactus; It was found compared to the other treatments. The sheep highlights were in rumination activity in said sequence (7:18 hours) as compared to others, indicating faster intake of the concentrate in your time of supply, as verified by (BEAUCHEMIN et al., 2008; DeVRIES \& KEYSERLINGKT，2009); if it is provided separately from the forage the animal can quickly eat all that amount.
It is consistent to the possibility that the intake of hay was fractionated 24 hours a day, with greater availability of rumination. The same authors emphasized that the hay offered once or twice a day might possibly be edible throughout the day, since ingestive behavior are competitive in the partition of time between the behavioral activities of ruminants.

Significant differences $(\mathrm{P}<0.05)$ in the time spent on ingestion and rumination were found between the different diets sequences when the ingestive behavior was divided into four periods (4-h interval from the first feeding) (Table 3).

Table 3. Time spent on eating and rumination in sheep fed in different sequences of food during circadian periods

\begin{tabular}{lccccccc}
\hline \multirow{2}{*}{ Periods } & \multicolumn{7}{c}{ Treatments } \\
\cline { 2 - 8 } & 1 & 2 & 3 & 4 & 5 & $\mathrm{P}$ & SEM $^{1}$ \\
\hline Intervals (h) & 72 & 65 & 55 & 65 & 63 & $>0.05$ & 0.65 \\
\hline $7: 00-11: 00$ & 17 & 14 & 6 & 23 & 11 & $>0.05$ & 3.70 \\
$11: 00-15: 00$ & 87 & 85 & 92 & 76 & 90 & $>0.05$ & 0.91 \\
$15: 00-19: 00$ & $14^{\mathrm{b}}$ & $17^{\mathrm{b}}$ & $36^{\mathrm{a}}$ & $27^{\mathrm{ab}}$ & $25^{\mathrm{ab}}$ & 0.045 & 2.23 \\
$19: 00-23: 00$ & 10 & 3 & 10 & 4 & 6 & $>0.05$ & 3.65 \\
$23: 00-3: 00$ & 3 & 1 & 4 & 4 & 5 & $>0.05$ & 7.45 \\
$3: 00-7: 00$ & \multicolumn{7}{c}{ Rating (min/day) } \\
\hline $7: 00-11: 00$ & $26^{\mathrm{b}}$ & $12^{\mathrm{b}}$ & $55^{\mathrm{a}}$ & $8^{\mathrm{b}}$ & $67^{\mathrm{a}}$ & 0.0009 & 2.16 \\
$11: 00-15: 00$ & $81^{\mathrm{a}}$ & $41^{\mathrm{b}}$ & $94^{\mathrm{a}}$ & $35^{\mathrm{b}}$ & $106^{\mathrm{a}}$ & 0.0001 & 1.28 \\
$15: 00-19: 00$ & 3 & 9 & 1 & 15 & 1 & $>0.05$ & 8.59 \\
$19: 00-23: 00$ & 56 & 75 & 35 & 56 & 44 & $>0.05$ & 1.91 \\
$23: 00-3: 00$ & $93^{\mathrm{ab}}$ & $118^{\mathrm{a}}$ & $105^{\mathrm{ab}}$ & $115^{\mathrm{a}}$ & $80^{\mathrm{b}}$ & 0.049 & 0.96 \\
$3: 00-7: 00$ & 133 & 153 & 130 & 135 & 127 & $>0.05$ & 0.63 \\
\hline
\end{tabular}

Means followed by different superscripts in the same row are significantly different $(\mathrm{P}<0.05)$, SNK test. $1=$ Standart error of mean.

High non-fiber carbohydrates (NFC) contents diets, such as spineless cactus (FERREIRA et al., 2009), may not stimulate rumination and salivation, which can reduce the ruminal $\mathrm{pH}$ and lead to acidosis Beauchemin et al. (2003), altering the microbial population and reducing ruminal digestibility. Thus, intake is reduced and fiber fermentation is compromised. The NFC and neuter detergent fiber (NDF) balance in the diet is important to maintain $\mathrm{pH}$ and does not compromise the feeding behavior. 
Therefore, when ruminal $\mathrm{pH}$ (Figure 1) was measured at 9:00h the treatments TMR, 2 and 4 had smaller values, indicating selectivity for ingredients with high NFC (concentrate and spineless cactus) immediately after feeding in the morning. Similar behavior was observed at 11:00h. These observations support the expectation of diet selection by sheep in the different periods.

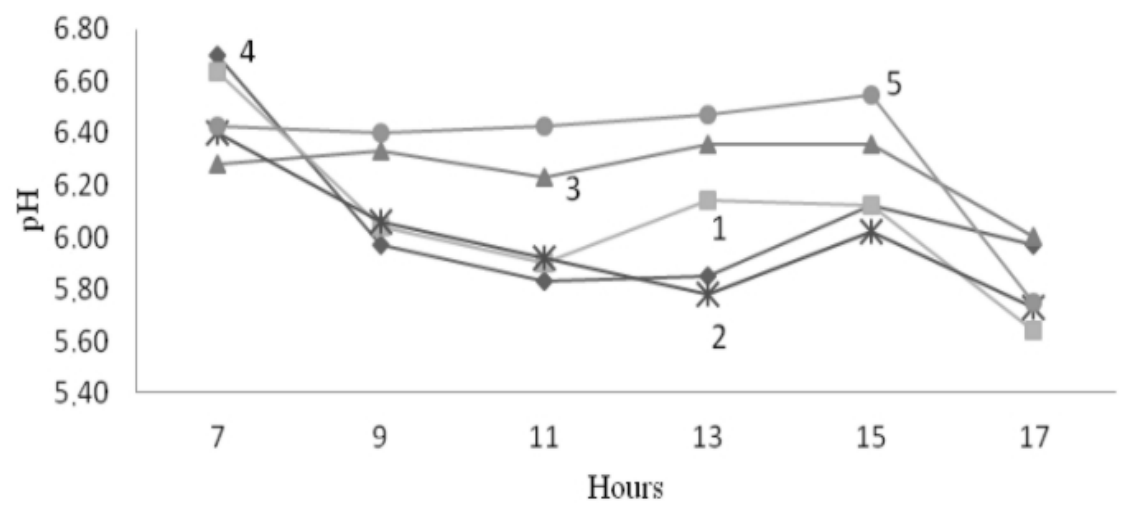

Figure 1. The $\mathrm{pH}$ of the ruminal fluid of sheep fed different sequences of food $($ Treatments $=1,2,3,4$, and 5)

These findings differ from those presented by Silva et al. (2005); DeVries \& Von Keyserlingkt (2009) and Vilela et al. (2010), who reported that TMR provides a more adequate balance of nutrients, reducing selectivity and imbalance between the diet offered and the food consumed. This suggests that animals prefer ingredients with greater acceptability, such as spineless cactus and concentrate. In the period from 19:00 to 23:00h (Table 3), animals on sequence 3 had higher eating time (36 minutes) than those on TMR and sequence 2 (14 and 17 minutes, respectively).

Perhaps greater amounts of concentrate were ingested in the morning, with transfer of hay ingestion for the period 19:00 - 23:00h. Moreover, the amount of nutrients (concentrate and spineless cactus) offered from $15: 00$ to $16: 00 \mathrm{~h}$ likely led to greater ingestion times in the observation period. This suggests that the food was more acceptable to the animals and thus greater amounts were voluntary consumed, thereby extending to ingestion. According to Ferreira (2005), large amounts of spineless cactus can be consumed, likely due to its low dry matter (DM) content and high acceptability. This consume depends on the animal category, feeding strategy, diet composition and number of meals. Feed with high NFC contents are rapidly fermented in the rumen, decreasing the ruminal $\mathrm{pH}$ and increasing of NFC's passage rate (CAVALCANTE et al., 2008). Therefore, the spineless cactus is a carbohydrate with high solubility, enabling increased ingestion time, unlike the ingredients provided in the treatments: TMR or (concentrate, spineless cactus, concentrate, hay), around to the time from 19 to 23 hours, where high fraction undegradable of hay NDF could be present.

Feeding with TMR resulted in a shorter ingestion time (14 $\mathrm{min})$ than feeding with sequence 3 , perhaps due to the 
effect of the twice-a-day feeding strategy $(50 \%$ in the morning and 50\% in the afternoon). These findings support the inferences outlined by Dulphy \& Faverdin (1987), who suggested that feedlot ruminants fed twice a day eat a large meal immediately after food is offered, which stimulates the beginning of the meals. In this study, greater ingestion times were detected, due to the urgency of the animals beginning to eat in response to stimuli related to feeding (CHASE et al., 1976).

These stimuli were not present in other periods, which decreased the activity. The positive effect of the feeding strategy in the beginning of meals is highlighted by the higher activity values recorded concomitant with the offering of food, as well as by the concentration of ingestion in the photoperiod (i.e., daytime), consistent with other research with sheep (HÜBNER et al., 2008). Much of this behavior is probably due to psychogenic factor, in which the frequency of the provision favors the stimulation of the voluntary consumption.

Mertens (1994) suggest that psychogenic regulation involves the behavioral response of the animal in front of the factors inhibiting or stimulating food or feed management. Reduced $\mathrm{pH}$ was observed when spineless cactus/concentrate and concentrate/spineless cactus (treatment 2 and 4) was offered in the morning (Figure 1), with lower $\mathrm{pH}$ values at 9:00; 11:00 and 13:00h observed on sequence 2 and 4 due to the lower NDF content, which resulted in less time spent on rumination on period 11:00 to 15:00h (41 and 35 minutes, respectively) as shown in Table 3 . According to Mendonça et al. (2004), NDF content and quality alter rumination time. Animals receiving sequences 3 and 5 spent more time ruminating (55 and 67; 94 and 106 minutes, respectively) at 7:00-11:00 and $11: 00-15: 00 \mathrm{~h}$ than those that not received hay in the morning, except for TMR (81 minutes), which showed similar behavior of according Table 3 . Higher ruminal $\mathrm{pH}$ values were observed for these sequences ( 3 and 5), at 11,13 and $15 \mathrm{~h}$ (Figure 1), possibly due to the effect of fiber of roughage of tifton grass hay.

According to Zebeli et al. (2008) physically effective fiber in the ration is the most efficient nutritional measure to alleviate the $\mathrm{pH}$ decline after a meal. Less time spent on rumination was observed in TMR (26 minutes) from 7:00-11:00h, similar to the treatments without hay feeding in the morning, leading to the inference that the selection of ingredients (spineless cactus and concentrate) is more acceptable and did not strongly stimulate rumination; lower $\mathrm{pH}$ was also observed in this period (Figure 1).

Furthermore, within these periods, sequences 2 and 4 were associated with higher dry matter and organic matter apparent tract digestibility $(\mathrm{P}<0.05)$ than TMR, 3 and 5 (Table 2).

In relation to this superiority of digestibility for treatments 2 and 4 , it is important infer that even with no significant change in intake between the different sequences of the diet, this increase in digestibility of dry matter and organic matter, took place because the high concentration of soluble carbohydrates, available in the morning. Even though the spineless cactus and concentrate not considered stimulants rumination, the spineless cactus provides intense chewing and consequently increased production of saliva, with considerable amounts of pectin favoring the production of acetate (notably weaker acid). Probably 
this behavior provided better rumen fermentation pattern throughout the day, with more intense chewing, thus increasing saliva production, reflecting an improvement in digestibility. Misra et al. (2006) emphasized that the spineless cactus has a large buffering capacity, which in turn promotes increased microbial activity, concomitantly with a more efficient fermentation.

It is relevant to mention that spite of lower $\mathrm{pH}$ values observed during this period (morning) for their feeding sequences (Figure 1) they always remained above 5.64, not going beyond critical values. Thereby did not affect cellulolytic bacteria fermentation or NFC content digestibility, but they did alter the rumination time relative to the feeding of tifton hay in the same period. According to Van Soest (1994), Miron et al. (2004) and Carvalho et al. (2006); the time spent on rumination is affected by the diet composition and may be proportional to the cell wall content of the roughage. In the 23:00-03:00h period, less time spent on rumination was observed as hay distribution advanced, supported by the results of the 5 sequence ( $80 \mathrm{~min}$ ) vs 2 and 4 (118 and $115 \mathrm{~min}$, respectively), certainly the animals ingesting hay in the afternoon spend longer on activity than animals receiving other treatments.

The different feeding strategies for supply the ingredients of a spineless cactus based in diet do not alter the ingestive behavior of sheep with respect to total daily rhythms. The feeding strategy with separated ingredients as concentrated/spineless cactus/ concentrate /hay or spineless cactus /concentrate /hay/concentrate, besides showing superiority in nutrient digestibility also reduces the work for the producer, being recommended to use these ingredients in feed for sheep with no clear negative effect on the parameters evaluated.

\section{REFERENCES}

BEAUCHEMIN, K.A.; YANG, W.Z.; RODE, L.M. Effects of particle size of alfalfa-based dairy cow diets on chewing activity, ruminal fermentation and milk production. Journal of Dairy Science, v.86, n.2, p.630-643, 2003.

BEAUCHEMIN, K.A.L.; ERIKSEN, L.; NORGAARD, P.; RODE. L.M. Salivary secretion during meals in lacting dairy catle. Journal of Dairy Science, v.91, p.2077-2081, 2008.

CARVALHO, G.G.P.; PIRES, A.J.V.; ROBÉRIO, R.S.; RIBEIRO, L.S.O.; CHAGAS, D.M.T. Feeding behavior of lactating Alpine goats fed diets containing different dietary levels of forage neutral detergent fiber. Revista

Brasileira de Zootecnia, v.35, n.2, p.562-568, 2006.

CAVALCANTE, M.C.; BATISTA, A.M.V.; GUIM, A.; LIRA, M.A.; RIBEIRO, V.L.; RIBEIRO NETO, A.C. Intake and ingestive behavior of sheep and goats fed with cactus pear (Opuntia ficus-indica Mill) and prickly pear (Opuntia sp.).Acta Science Agronomy, v.30, n.2, p.173-179, 2008.

CHASE, L.E.; WANGSNESS, P.J.; BAUNGARDT, B.R. Feeding behavior of steers fed a complete fixed ration.

Journal of Dairy Science, v.59, n.11, p.1923-1928, 1976.

COELHO DA SILVA, J.F.; LEÃO, M.I. Fundamentos da nutrição de ruminantes. Piracicaba: Livroceres, 1979. 380p. 
COSTA, S.B.M.; FERREIRA, M.A.; PESSOA, A.R.S.; BATISTA, A.M.V.; RAMOS, A.O.; CONCEIÇÃO, M.G.; GOMEZ, L.H.S. Tifton hay, soybean hulls and whole Cottonseed as fiber source in spineless cactus diets for sheep. Tropical Animal Health and production, v.44, n.2, p.1993-2000, 2012.

DeVRIES, T.J.; Von KEYSERLINGKT, M.A.G. Short Communication: Feeding method affects the feeding behavior of growing dairy heifers. Journal of Dairy Science, v.92, n.3, p. 1161-1168, 2009.

DULPH, J.P.; FAVERDIN, P. L'ingestion alimentaire chez Les ruminants modalités et phénomenès associés. Reproduction Nutrition and Dévelopement, v.27, p.129-155, 1987.

FERREIRA, M.A. Palma forrageira na alimentação de bovinos leiteiros. Recife: UFRPE, 2005. 83p.

FERREIRA, M.A.; SILVA, F.M.; BISPO, S.V.; AZEVEDO, M. Strategies for the supplementation of dairy cows in the Brazilian semi-arid. Revista

Brasileira de Zootecnia, v.38, p.322329, 2009. Supl. especial.

FRANÇA, S.R.L.; GONZAGA NETO, S.; PIMENTA FILHO, E.C.; MEDEIROS, A.N.; TORREÃO, J.N.C.; MARIZ, T.M.A.; COSTA, R.G.

Ingestive behavior of Morada Nova ewes during the last third of pregnancy fed different levels of metabolizable energy.

Revista Brasileira de Saúde e Produção Animal [online], v.10, n.1, p.73-84, 2009.

HÜBNER, C.H.; PIRES, C.C.; GALVANI, D.B.; CARVALHO, S.; JOCHIMS, F.; WOMMER, T.P.; GASPERIN, B.G. Feeding behaviour of lactating ewes fed diets containing different neutral detergent fiber levels. Ciência Rural, v.38, n.4, p.1078-1084, 2008.

MARTIN, P.; BATESON, P. Measuring behaviour an introductory guide. 3.ed. Cambridge, UK: Cambridge University Press, 2007.

MENDONÇA, S.S.; CAMPOS, J.M.S.; VALADARES FILHO, S.C.; VALADARES, R.F.D.; SOARES, C.A.; LANA, R.P.L.; QUEIROZ, A.C.; ASSIS, A.J.A.; PEREIRA, M.L.A.P. Ingestive behavior in dairy cows fed sugar cane or corn silage based diets. Revista

Brasileira de Zootecnia, v.33, n.3, p.723-728, 2004.

MERTENS, D.R. Regulation of forage intake. In: NATIONAL CONFERENCE ON FORAGE QUALITY EVALUATION AND UTILIZATION, 1994, Lincoln. Proceedings... Lincoln: University of Nebraska, 1994. p.450-493.

MIRON, J.; YOSEF, E.; NYCBACHAT, M.; ZENOU, A.; MALTZ, E.; HALACHMI, I.; BEN-GUEDALIA, D. Feeding behavior and performance of dairy cows fed pelleted nonroughage fiber byproducts. Journal of Dairy Science, v.87, n.5, p.1372-1379, 2004.

MISRA, A. K.; MISHRA, A. S.; TRIPATHI, M.K.; CHATURVEDI, O.H.; VAITHIYANATHAN, S.; PRASAD, R.; JAKHMOLA, R.C. Intake, digestion and microbial protein synthesis in sheep on hay supplemented with prickly pear cactus (Opuntia ficus-indica, Mill) with or without groundnut meal.

Small Ruminant Research, v.63, p.125134, 2006.

NATIONAL RESEARCH COUNCIL NRC. Nutrient requirements of small ruminants: sheep, goats, cervids, and new world camelids. Washington, 2007. $384 p$. 
NOCEK, J.E. Bovine acidosis: implications on laminitis. Journal of Dairy Science, v.80, n.5, p.1005-1028, 1997.

SHEKARCHIAN, S. Research about indicate the effect of concentrate feeding strategy on milk production and composition in dairy cows in Esfahan, Iran. Veterinary Research, v.5, n.3, p.63-67, 2012.

SILVA, A.E.V.N.; GUIM, A.; FERREIRA, M.A.; LIMA, L.E.; PESSOA, R.A.S.; SOSA, M.Y. Feeding strategies for diet based on forage cactus on the performance and digestibility in cows in late lactation. Acta Scientiarum Animal Sciences, v.27, n.2, p.269-276, 2005.

SILVA, D.J.; QUEIROZ, A.C. Análises de alimentos: métodos químicos e biológicos. 3 ed. Viçosa: UFV, 2002. $235 \mathrm{p}$.

UVIVERSIDADE FEDEWRAL DE VIÇOSA - UFV. SAEG- Sistemas para análise estatística e genética. Versão 8.0. Viçosa, 2007. 150p.
Van SOEST, P.J. Nutritional Ecology of the Ruminant. 2nd ed. Ythaca, New York: Cornell University Press, 1994.

VILELA, M.S.; FERREIRA, M.A.; AZEVEDO, M.; MODESTO, E.C.; FARIAS, I.; GUIMARÃES, A.V.; BISPO, S.V. Effect of processing and feeding strategy of the spineless cactus (Opuntia ficus-indica Mill.) for lactating cows: Ingestive behavior.

Applied Animal Behaviour Science, v.125, n.1, p.1-8, 2010.

ZEBELI, Q.; DIJKSTRA, J.; TAFAJ, M.; STEINGASS, H.; AMETAJ, B.N.; DROCHNER, W. Modeling the adequacy of dietary fiber in dairy cows based on the responses of ruminal $\mathrm{pH}$ and milk fat production to composition of the diet. Journal of Dairy Science, v.91, n.5, p.2046-2066, 2008.

Data de recebimento: 12/06/2013

Data de aprovação: 26/02/2014 